\title{
What Do You Know About "Constructed by China"?
}

\author{
XueYu Ma \\ School of Management, Northwestern Polytechnical University, Xi'an City, Shaanxi Province \\ China \\ E-mail: maxueyu2013@163.com
}

Keywords: "Constructed by China"; China's foreign project contracting; Go Out Policy

\begin{abstract}
Since the 21st century, with the rapid growth of China's foreign project contracting, "Constructed by China" has appeared around the world. However, whether it should be encouraged and how to develop it is a problem that perplexes the Chinese government and enterprises. Based on accurate data, this paper analyses the current situation of China's foreign project contracting and presents its effect on China's economy. It is concluded that with the support of Go Out Policy, foreign project contracting is going to be a new growth point for Chinese foreign economy and gives a new impetus to Chinese sustained economic development. Therefore, I propose some countermeasures for government and enterprises to develop foreign project contracting, with the hope that they will be helpful.
\end{abstract}

\section{Introduction}

International project contracting is an important form of a country's foreign trade. So it's significant to follow the situation of international construction markets and enterprises so as to verify whether a country has entered the foreign market or not. Low Sui Pheng (1991), using absolute and relative measures, demonstrated that both developed and developing countries offered larger construction markets, so the role of marketing should be extolled in construction, especially international contracting. Gunhan Suat and Arditi David (2005) talked about how construction companies made a decision for international expansion in complex international environment and provided some methods for those companies to test if they are ready to enter foreign markets. Dublin's Research and Markets (2014) showed that the international construction aggregates markets will grow in every region in recent years. The most authoritative academic journal in America in the field of international construction market, Engineering New-Record (ENR) has been publishing the situation of international project contracting every year and forecasting its prospects including projects and contractors.

Under this circumstance, it's also important for China to research the prospect of foreign projects contracting and the highest usage of it. Therefore, this paper is analyzing the current situation of China's project contracting and its positive effect on China's economy. It is also suggesting some effective measures to the government and enterprises to develop the China's project contracting.

\section{The Development of China's Foreign Project Contracting}

\section{The history of China's Foreign Project Contracting}

China's foreign project contracting derived from the foreign aid projects in the mid of 20th century and the countries getting aid gradually expanded to Asia, Africa, Latin America and South Pacific. Accepting the suggestions of other countries, China assisted them in self-financing in public projects and infrastructures which had formed the special pattern in China.

The Chinese government provided great support to the development of foreign project contracting and put forward some measures. In 2001, the government proposed the Go Out Policy and then kept encouraging the foreign project contracting. In 2013, the government pointed out that both enterprises and individuals were allowed to invest and contract works overseas, which has brought new 
opportunities for China's foreign cooperation.

\section{The Current Situation of China's Foreign Project Contracting}

Since 2000, China's foreign project contracting has been developing continuously, both in the aspect of the value of turnover fulfilled (Fig.1) and the contracted value (Fig.2). According to the National Bureau of Statistics in 2013, the value of turnover fulfilled is 131.74 billion, the annual growth rate of which is $39 \%$ and the contracted value reached 171.63 billion. Meanwhile, the scales of projects are expanding. Among all the project contracts the value of 393 project contracts surpassed one hundred million, occupying $66 \%$ of the total year. As to the contractors, there are 55 enterprises were selected in the world's largest 250 international contractors by ENR in 2013.

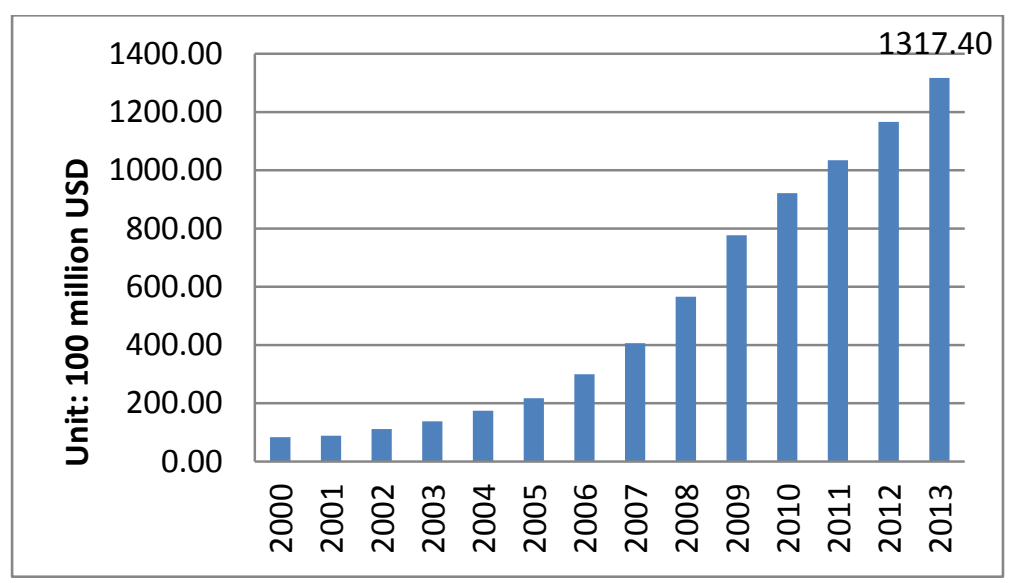

Fig.1. The situation of the value of turnover fulfilled in China's project contracting



Fig.2. The situation of contracted value of China's project contracting

\section{Regional Distribution}

Until 2006, the diversified international market of China's foreign project contracting initially came into being. It accounts for a large proportion in Asia and Africa and a small one in Latin America, Europe and North America. We have noticed a rising tendency in foreign project contracting in recent five years (Fig.3). 


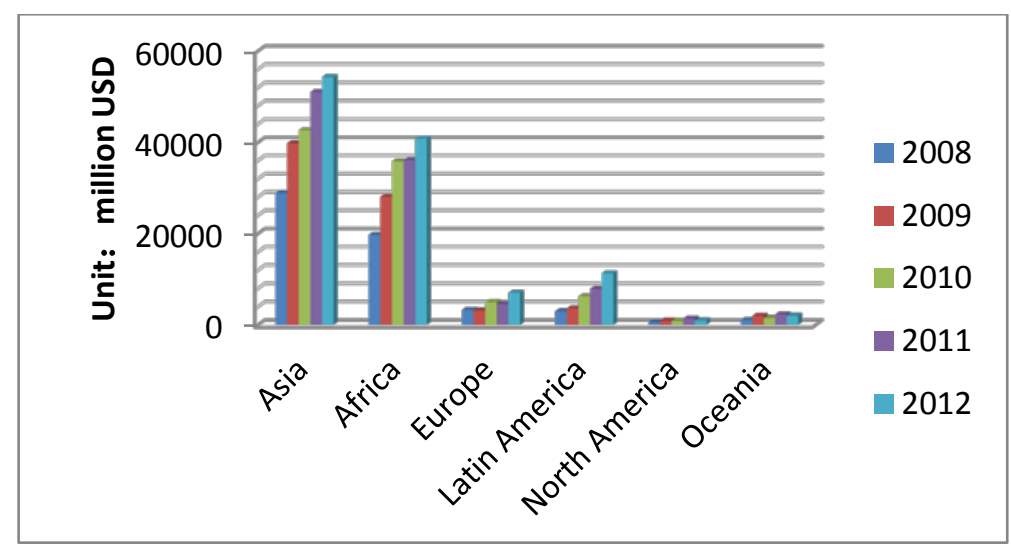

Fig.3. Distribution and tendency of the value of turnover fulfilled in China's projects

As the traditional market, Asia and Africa has always occupied large proportion in China's project contracting, especially in recent years (Fig.4). In 2012, the proportion of Asian market in total amount of China's foreign project contracting is $46.56 \%$ and the African market takes up $35.02 \%$. In other areas, there is an obvious increase in Latin America and Europe, whereas in North America and Oceania, the proportion has maintained a same level (Fig.5).



Fig.4. Changes on China's projects'value of turnover fulfilled in Asia and Africa

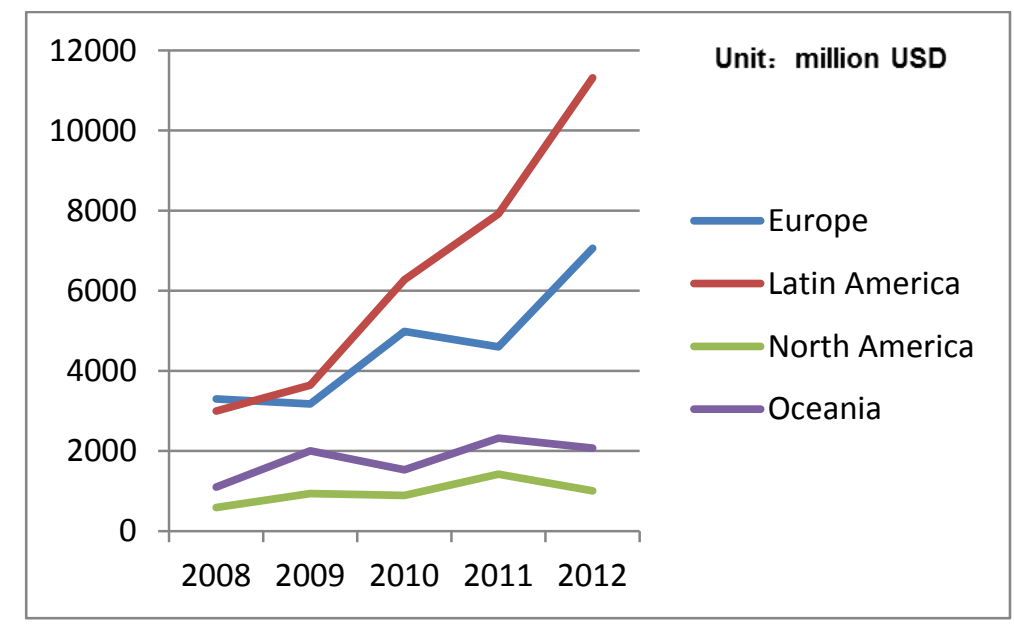

Fig.5. Changes on China's projects'value of turnover fulfilled in other areas

\section{Industrial Distribution}

The industries participating in China's foreign project contracting are expanding gradually. It is transforming from the simple construction project based on labor-intensive to capital and technology-intensive such as electricity, petrochemical industry, telecommunication, transportation 
and so on. Except the housing construction, the amount of others surpassed 60\% in 2012 (Table.1).

Table.1. The contracted value and proportion in different areas of investment in 2012

\begin{tabular}{|c|c|c|}
\hline Area of Investment & Contracted Value (Billions) & Proportion \\
\hline Housing Construction & 32.08 & $20.50 \%$ \\
\hline Transportation & 35.62 & $22.76 \%$ \\
\hline Electricity & 21.27 & $13.59 \%$ \\
\hline Telecommunication & 17.65 & $11.28 \%$ \\
\hline Petrochemical Industry & 17.16 & $10.97 \%$ \\
\hline
\end{tabular}

\section{Comparison on the Value of Turnover Fulfilled in the World}

There are seven countries occupied large proportion in international project contracting, including USA, Spain, Germany, France, Italy, China and South Korea. The projects of China and Spain increased rapidly from 2007 to 2012 (Fig.6). Due to the impact of economic crisis in 2008, other countries decreased with different degrees whereas China maintained an upward trend. Since 2011, many of developed countries have recovered so that the prospects of international project contracting are promising.

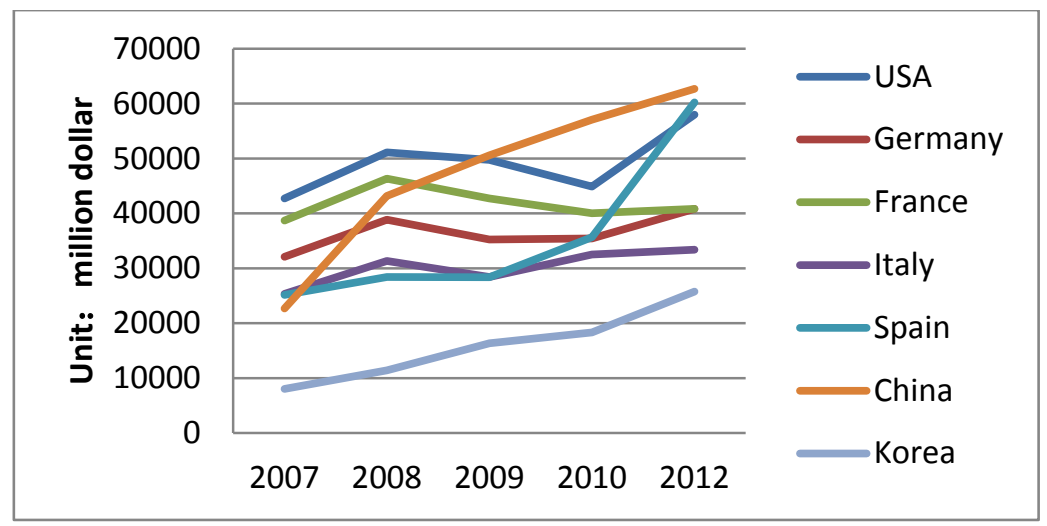

Fig.6. The value of turnover fulfilled in major countries

According to the Chinese Commerce Department, among the world's largest 225 international contractors in 2012, 52 Chinese enterprises achieving 62708.1 million turnovers, occupied 13.8\% in world's total amount and ranked No.1. On the other hand, 12 Spanish enterprises got 60211.0 million occupying 13.3\%, ranked No.2. It followed by 26 American enterprises which occupied $12.8 \%$. It is quite obvious that there is a strong momentum of China's project contracting. With the sustainable growth of economy and government strategies, China is going to be a bellwether of international project contracting. However, according to the world's largest 250 international contractors in 2013 by ENR, there are only six Chinese enterprises in top 50 as well as China Communications Construction Company Limited placed in top ten, but its turnover was far below the Spain's company Grupo ACS which had ranked first, which was indicating Chinese contractors that they still have a long way to go.

\section{The Effect of Foreign Project Contracting on China's Foreign Trade}

\section{The Progression of China's Economic Development}

Based on the official data, Chinese import and export value was 3867.1 billion in 2012 and 4159.6 billion in 2013; respectively, the proportion of foreign project contracting occupied $3 \%$ and $3.2 \%$. It showed that foreign project contracting has a positive effect on improving economy, but the function is not effective at present. However, because of the swift growth of China's project contracting, it will become a significant aspect in China's foreign trade. 


\section{The Expansion in China's Commodity Export}

According to the customs data, the number of export commodities by foreign project contracting rises every year. The value of export commodities had been increased from 199 million in 1995 to 14.78 billion in 2012. Especially after 2004, the growth speed of gross export commodities kept above $50 \%$ annually. Therefore, foreign project contracting, promoting not only the number of commodities but also the rates of domestic commodities in gross export. It indicated that foreign project contracting have an essential function in domestic commodities export.

\section{The Improvement of China's Foreign Trade Structure}

The main industries of foreign project contracting involve the construction and manufacturing. The category of it is typical like mechanical and electrical products occupy 80\%; vehicles, ships, and transportation equipment take up about $7 \%$. Therefore, foreign project contracting exports are mainly in capital and technology-intensive, which have a positive influence on foreign trade structure.

\section{The Necessities of the Upgrades in China's Enterprises}

Nowadays, the pattern widely used in the international construction market includes contracting with a capital and a package of turn-key project. It required that China's enterprises have to develop in technology, capital and innovation. Faced with the fierce international competition, China's enterprises should first make some upgrades and innovations on business mode, technology and staff education. Then it is possible for them to outstrip the developed countries such as Spain, USA and Germany. Hence, it is foreign project contracting that makes China's enterprises consolidate the technological advantages and enlarges the input of technology research and R\&D investment.

\section{The Measures for China's Foreign Project Contracting}

\section{Insist on the Go Out Policy}

On the one hand, the government should insist on the Go Out Policy and encourage enterprises to develop foreign project contracting and relevant industries. It is also important to strengthen the supervision, guidance and services to contractors as well as support the large and superior ones. On the other hand, the job of legislating and improving relevant policies should not be neglected. The government may as well indicate direction for enterprises in revenue, finance, foreign exchange and commodity inspection. It is good for the enterprises to develop business if government improves the financial service system and expands financial support.

\section{Optimized Industrial Structure, Building up Enterprise's Competitive Advantages}

Except for the economic profits, enterprises should also pay much attention to social responsibility, quality of projects and corporate images. The data showed that among all the projects in developed countries, $75 \%$ of them are investment business. Thus, China's enterprises should not only achieve the innovation of the business models but also develop foreign investment business relevant to project contracting. In addition, enterprises should take personnel training and incentive system into consideration; solve the problems which appeared in international business such as quality and scale of staff and their working ability. Meanwhile, to stimulate the vitality of workers and promote managerial level is beneficial to build up competitive advantages.

\section{Market Expansion and Achieving Diversification of Export}

To expand the global market, Enterprises should meet the need of market and take the following suggestions. First, analyze the infrastructure situation in foreign countries and judge its capacity and structure on the basis of the selection on entering into the market. After entered into the international market enterprises may require changing original simple business models and expanding the industrial chain. Second, find out the main rivals and make differentiation strategy based on its own features so as to improve overall strength. Meanwhile, learn some laws and regulations from other countries and take measures to deal with risks. Third, according to the world economic development and periodic features, enterprises should take concrete countermeasures in terms of resources and financial situations. To make sure they have the ability to deal with incidents flexibly and maintaining the continuous development. Moreover, if enterprises want to achieve diversification of export, there 
is no doubt that accomplishes the transformation from traditional manufacturing advantages into technical superiority.

\section{Conclusion}

With the increasing investment on infrastructure from developed countries, some developing countries are speeding up on the way of urbanization. Hence, there comes a great growth in the need of the global construction market, and the international project contracting is on the highway of development. In recent years, with the support of Go Out Policy, Chinese projects involving construction, transportation and communication etc. are founded everywhere, and these projects have enjoyed high reputation. It shows that foreign project contracting is gradually becoming the breakthrough of upgrade of Chinese enterprises and creating a new economic growth area in China.

Thus, Chinese enterprises should be encouraged to develop foreign project contracting and make contributions to huge projects with "Constructed by China”.

\section{References}

[1] Low Sui Pheng: World Markets in Construction. Construction Management \& Economics. Feb.1991, Vol. 9 Issue 1, p63. 9p.

[2] Gynhan Suat, Arditi David: International Expansion Decision for Construction Companies. Journal of Construction Engineering and Management. Aug.2005,Vol.131 Issue 8, p928-937.

[3] Research and Markets: Concise Analysis of the International Construction Aggregates Market Forecasts to 2017.Dublin (02/13/2014), in press.

[4] Engineering New-Record (ENR): The Top 250 International Contractors, 2014.

[5] Information on http://www.stats.gov.cn/tjsj/ndsj/ 